\title{
THE TESTING OF TEACHER'S COMPETENCE MODEL FROM MULTIMEDIA EXPERTISE PROGRAM USING CONFIRMATORY FACTOR ANALYSIS
}

\author{
Muhammad Rafie Pawellangi ${ }^{1} \&$ Hakkun Elmunsyah ${ }^{2}$ \\ ${ }^{1}$ PPPPTK Bidang Otomotif dan Elektronika, Jl. Teluk Mandar Tromol Pos No.5, Arjosari, Malang, 65126 \\ ${ }^{2}$ Universitas Negeri Malang, Jl. Semarang 5 Malang 65145 \\ e-mail: rafie@kkpi.or.id \& hakkun@um.ac.id
}

\begin{abstract}
The Testing of Teacher's Competence Model from Multimedia Expertise Program Using Confirmatory Factor Analysis. The research aims to test the teacher's competence model which becomes the basis of evaluating the teacher's competence in Indonesia as well as the basis of developing the education and training to improve the competence. The tested model involves several levels of measurement construct, from competence dimension, competence group, to expertise group. The analyzed data in the research is the result of test namely Teacher's Competence Test of Vocational High School teachers teaching Multimedia subject $(\mathrm{N}=2,744)$. The data is analyzed using Confirmatory Factor Analysis (CFA) approach. The analysis result shows that the tested model has satisfying model acuracy which means the model represents the actual data. The Root Mean Square Error of Approximation $(\mathrm{RMSEA})=0.000(<0.08), \mathrm{CFI}=1.000(>0.95), \mathrm{TLI}=1.000(>0.95)$. The findings also show that the model is able to explain the teacher's phenomenon in the real world. Therefore, the evaluation process against the teacher's competence and the intervention in the competence development using this model are empirically supported.
\end{abstract}

Keywords: teacher's competence model; multimedia expertise; confirmatory factor analysis

\begin{abstract}
Abstrak: Pengujian Model Kompetensi Guru Program Keahlian Multimedia Menggunakan Confirmatory Factor Analysis. Penelitian ini bertujuan untuk menguji model kompetensi guru yang menjadi dasar evaluasi kompetensi guru di Indonesia serta dasar pengembangan pendidikan dan pelatihan untuk meningkatkan kompetensi. Model yang diuji melibatkan beberapa level konstruk pengukuran, dari dimensi kompetensi, kelompok kompetensi, hingga kelompok keahlian. Data yang dianalisis dalam penelitian ini adalah hasil tes yaitu Uji Kompetensi Guru guru Sekolah Menengah Kejuruan yang mengajar mata pelajaran Multimedia $(\mathrm{N}=2,744)$. Data dianalisis dengan menggunakan pendekatan Confirmatory Factor Analysis (CFA). Hasil analisis menunjukkan bahwa model yang diuji memiliki ketepatan model yang memuaskan yang berarti model tersebut mewakili data aktual. Root Mean Square Error Approximation $(\mathrm{RMSEA})=0,000(<0,08), \mathrm{CFI}=1.000(>0,95), \mathrm{TLI}=1.000(>0,95)$. Hasil temuan ini juga menunjukkan bahwa model tersebut mampu menjelaskan fenomena guru di dunia nyata. Oleh karena itu, proses evaluasi terhadap kompetensi guru dan intervensi dalam pengembangan kompetensi menggunakan model ini didukung secara empiris.
\end{abstract}

Kata kunci: model kompetensi guru; keahlian multimedia; confirmatory factor analysis

The development of competence models is a continuous process because changes in every aspect of this very fast life need to be accommodated (JovanovaMitkovska \& Hristovska, 2011). The model is a concept that explains the relationship between a phenomenon and another phenomenon based on the basis of a particular theory. Although the model is a simplification of life that contains various complex phenomena, it has many functions. The competence model is a model that needs to be continuously developed or evaluated because it has a highly practical value. Competence models need to adjust to the demands of that complexity. The development of competence models (e.g. teacher's competence model) in education is not as much as that in industry and organizations (Grealish, 2006). On the 
other hand, the development of teacher's competence model that has been developed has some limitations. For example, the model is still partial because it does not accommodate the various dimensions or specificities that exist (Cabaní et al., 2014), is still theoretical because it has not been empirically tested (Piri et al., 2016) or is still coercive from top to bottom because it is a policy given directly from policy makers in education (Gokce, 2015).

Research on the development of competence model in Indonesia, especially for the population of teachers has not done much. Models that have been developed have limitations both in terms of less update and low coverage. Currently, the need for teacher's competence model is urgent. The urgency of this need is due to several things, for example, firstly, information about the teacher's proficiency level or profile in Indonesia is an important capital to see the potentials in the field of education. Secondly, by knowing the level or profile, the policy target related to teacher will be in line with empirical conditions

Currently, the government through the Directorate General of Teachers and Education Personnel (GTK) has responded the challenge in identifying teacher's proficiency level and profile through the implementation of nationwide Teacher's Competence Test (UKG). The test is developed based on the competence model used to construct the structure, test specifications, and tested items. The competence model is developed by accommodating several things, such as the current challenges in the field of education or the findings in the implementation of previous education. Competence development is a very important issue in today's society because the performance of competent people is badly needed to support one's success in the job. The developed competence model has not been empirically tested so that its conformity with the phenomenon in the field is still minimal. As a result, if it is implemented practically, its implementation is not likely to run effectively and its result will not be optimal.

Some experts define competence as a functional quality a person must possess adequately in order to be able to accomplish his/her tasks well. The quality here contains knowledge, abilities, skills, judgments, attitudes, and values. Competence refers to what the individual knows and what he can do ideally (Prachagool et al., 2016). On the other hand, performance refers to what is actually done based on existing conditions. Furthermore, competence includes knowledge and abilities while performance contains the process in accessing and utilizing a number of facilities to overcome the task being handled. It means that competence and performance have quite distinct differences. Competence contains a number of individual capacities while performance includes the completion of tasks based on the resources provided.

There is a lot of literature that explains the dimensions of teacher's competence. Develop a competence model containing three dimensions, namely teaching, coordination, and leadership (Molenaar et al., 2009). In the model, each of them has knowledge, attitude, and skills. Meanwhile, the context covering the teacher's competence described in the model is self-development, organization, execution, training, assessment, and evaluation. Meanwhile, in other models, the teacher's competence is divided into two dimensions, namely the dimension related to specific learning activities and the dimension related to the utilization of facilities for assessment and implementation of learning in the classroom (Elmunsyah et al., 2019). There are two dimensions of competence in the model being developed, namely global dimension and specific dimension (Bertschy et al., 2013). The global dimension relates to general principles in teaching methods, group processes, and research. Both dimensions relate to teaching skills such as question stimulation, teaching creativity, identification, and problem solving. Teachers also have specific teaching competences such as identifying, teaching, and counseling to talented children who are at a certain degree more important than the implementation of global teaching strategies.

A fairly comprehensive division of competence dimension is the division of teacher's competence dimension used by the Ministry of Education and Culture, i.e. pedagogic, personality, social and professional dimensions. But for now, the government policy still emphasizes on two competence dimensions, which are professional and pedagogic dimensions. One of the missions of this research is whether the use of the two dimensions is sufficient to explain the complexity and variation in teacher's competence. The two-dimension selection has a strong theoretical basis because some literature describes the use of these two dimensions. From the various divisions of the teacher's competence dimensions, the division of teacher's competence is divided into two dimensions, namely pedagogy and professionals which are lately studied in many kinds of literature (Rizza \& Elmunsyah, 2018; Tasiam et al., 2017). In certain models, these two dimensions are aligned with other dimensions. For example, a three-dimension model of the teacher's competence: key di- 
mensions, professionalism in general, and specific pedagogy (Usoltzev et al., 2016). However, the division of two dimensions of competence into pedagogical and professional dimensions has a stronger theoretical basis compared to the division into dimensions other than pedagogy and professional (Gourier, 2010).

Pedagogic competence is based on what is contained in the subject and knowledge of the student learning process (Drovnikov et al., 2016). Furthermore, pedagogic competence is expected to include skills in teaching, mastery of theories, and attitudes to self-development. Pedagogic competence is a product of self-education, self-improvement, and self-development to be a specialist in the future. The formation and development of pedagogic competence are related to the student's basic skills development like perception, communication, organization, engineering, research, and capabilities, all of which support the implementation of effective teaching and learning activities (Drovnikov et al., 2016). From the explanation above, it can be seen that the pedagogic competence contains teacher's mastery in the materials being taught which involve the context of novelty, breadth, and depth. Teachers with high pedagogic competence know not only much about the subject matter but also the latest developments and depth of the material.

The literature states that professional competence also includes the ability to implement educational programs by applying modern technology and interactive training and education methods (Kamalova, 2015). The concept of professional competence was initially popularized by (Chalmers University of Technology, 2013) which explains the specific capabilities that can address the need to complete tasks at work. In the COACTIV model developed to explain the lecturer's competence, it contains four elements which are procedural knowledge, professional values, beliefs, motivational, and professional regulatory skills (Baumert \& Kunter, 2013). There are experts who say that professional competence is not related to competence in general because it does not meet the definition of competence (Baumert \& Kunter, 2013). The definition of competence referred by Liakopoulou emphasizes on competence as a set of capabilities that support a person working professionally rather than a set of capabilities shown in an action. Through various explanations above, it can be concluded that the professional competence includes the ability of teachers to reflect on their own performance continuously in order to improve the professionalism.
In general, competence is a term most widely used in the discussion of a set of qualifications that must be possessed by an individual in order to have maximum performance at work. The competence model developed in this paper derives from that description. The teacher's competence is manifested into two dimensions, namely the pedagogic and professional dimensions. This dimension is the second level construct of the tested competence model. These two dimensions are derived into ten competence groups representing a series of competences in the form of a more operational construct. This group of competence is the third level construct. This expertise group is still universal, so it needs to be specified again into a more contextual construct that is in accordance with the existing subject called the teacher's skill which is the fourth level construct. The constructs linked to this specific skill are then described into indicators which become the manifestations of expertise in operational and measurable empirical performance. Each indicator is then translated into grain samples. It is named as sample because between one grain and other grains measuring the same skill is interchangeable. That is, the items are parallel because they have the same measuring content or measure on the same knowledge, attitude or behavior.

The competence model described above is generic; it means that it can be applied to various subjects. In this study, the authors use the application of this competence model in Multimedia Expertise Program Subject. In this model, the teacher's competence contains two competence dimensions, namely pedagogy and professional. The teacher's mastery on these two dimensions is shown by several competence groups. Each dimension contains ten competence groups and each of them includes one to four skills.

Factor analysis is a statistical test technique used to view the structure of data. A data sometimes does not represent a single dimension or phenomenon, but it represents some sub-factors or sub-phenomenon which, when combined, will form a building structure of a thing. These structures are more often called constructs (e.g. competence constructs). Since the construct is usually the measuring target of a test, the word construct is often called the measuring construct, meaning the construct is measured by a test. Factor analysis aims to identify the structure of a measuring construct, especially identifying how many constructive construct dimensions are, how the contribution of each dimension is in constructing constructs, and which indicators go into each identified dimension. 
Factor analysis is divided into two types. The first type is Exploratory Factor Analysis (EFA). This factor analysis identifies the structure of a measuring construct without involving the assumptions or hypotheses of the researcher. Researchers fully submit the structures that are formed (the number of dimensions and the indicators that fall within each dimension) in the analysis process performed by the computer program. The computer program will choose by itself how many dimensions are formed based on the correlation matrix created by the computer from the data being analyzed. The indicators that have similarities (have a high correlation) will be seen as one dimension. The result is that some dimensions contain various indicators.

The ssecond type is Confirmatory Factor Analysis (CFA). This analysis aims to confirm whether the dimensions hypothesized by the researchers fit the data. In this analysis, the researcher has a hypothesis about the structure of the measuring construct being tested, e.g. hypothesizing the dimensions in the construct is either two dimensions or three dimensions. In addition, researchers have also set which indicators fall into that dimension. The structure is called the measurement model, which is a model that connects the dimensions and indicators that measure it. The analysis results will reveal how far the tested model fits the data.

EFA and CFA have some similarities. For example, how much the indicator's contribution in manifesting the measured dimensions is seen through the factor loading parameter. The higher the factor loading, the greater the contribution of an indicator in manifesting the measured dimensions or constructs. Some authors suggest that factor loading rates should be above 0.30 (Liakopoulou, 2011). In determining dimension names, between the EFA and CFA approaches have some differences. The determination of the name of the EFA dimension is determined solely by the researchers because the dimensions formed are determined by the data. The name of the dimension is derived from the similarity of the content of the items within the dimension. Similar to EFA, the determination of dimension names in the CFA analysis is determined by the similarity of the content of the item, but before analyzing the researchers have prepared their own dimensions and indicators in it.

This study aims to examine the teacher's competence model which is the basis for the evaluation of the teacher's competence through UKG and Education and Continuous Training for Multimedia Teachers. This study examines a model that emphasizes the overall level of the construct by involving three levels of construct, starting from competence, competence dimension, to competence group. Testing the two models accommodates different purposes. If the first model identifies the construct validity in the teacher's competence model structure, the second model looks at the functioning of the indicators involved in the model. This study emphasizes on the appropriateness of model buildings by involving large constructs (competence dimension and competence group) so that detailed model testing is not performed.

\section{METHOD}

The study involved SMK teachers from 34 provinces $(\mathrm{N}=2,744)$ with the majority coming from East Java (24.2\%), Central Java (19.6\%), and West Java (12.6\%). Distribution of location of the participant's residence or workplace in each province is quite evenly because there is no dominant location in one province. From the employment status of teachers, the highest proportion is GTY/PTY $(30 \%)$, School Honor Teachers $(30 \%)$ and civil servants $(18.9 \%)$. Based on the gender of teachers, the number of male teachers $(71.6 \%)$ is higher than female ones $(28.3 \%)$.

The measurement instrument used in this research is the Teacher's Competence Test (UKG) in the Multimedia Program. The test consists of two dimensions, namely pedagogic and professional dimensions. Because they are different dimensions, the analysis of the items is done separately. The UKG test of the pedagogic dimension has reliability (KR 20) of 0.89 while professional dimension has a reliability of 0.95 . The testing using Rasch Model finds that this test has satisfactory psychometric properties. All grains have a satisfactory model accuracy which is indicated by an infit-outfit value in the range received ( 0.50 to 1.50$)$. Identification of the item-person map which explains how far the test in accordance with the variation of the level of competence of teachers also shows satisfactory results. The distribution of difficulty levels of the grains on the test has precision with the teacher's competency distribution.

In this study, the teacher's competence model was tested using Confirmatory Factor Analysis (CFA). The software program used to assist the analysis is MPLUS 7.0. The program performs analysis using maximum likelihood estimation technique. Before the data were analyzed, researchers applied the missing data imputation procedure using Winsteps 3.0 program. The function of applying this technique is to speed up the estimation process in 
CFA. Winsteps program is Rasch model-based analysis program that has the capability good enough to replace the lost data because this model can predict well what the person's item score based on the response pattern of all existing participants.

The properties identified in this analysis are: (a) the model's accuracy index; (b) the price and the significance of the item parameters; and (c) the identification of which dimension or indicator contributes the most in the constructed measurement construct. The model's accuracy index as a benchmark in determining the fit model is Tucker-Lewis Index (TLI) and Comparative Fit Index (CFI), which is expected to cost over 0.95 and root mean square error of approximation (RMSEA) whose price is expected under 0.08 (Hu \& Bentler, 1999). The parameters of the items studied are factor weights. The recommended weighting price is factor weight above 0.30 and significant at $95 \%$ level (Santos et al., 2016). To compare the contribution of each dimension or indicator, this study uses the effective contribution shown by the price of the square of the correlation (r-squared). The dimensions or indicators that contribute most in the formation of the measured construct are determined by the price of the largest squares correlation.

\section{RESULT}

The following sub-sections describes the result of this study. There are two main results, which are model accuracy and indicator parameter identi- fication. The results obtained from the test that describes on the method.

\section{Model Accuracy Test}

Testing of Model Type 1 gets satisfactory results of the model. Statistically, the model accuracy supported by the model accuracy index generated from the model testing is within the range indicating the exact model of the data. For example, the value of RMSEA $\approx 0.000(<0.08), \mathrm{CFI}=1.00(>$ $0.95), \mathrm{TLI}=1.00(>0.95)$. On the other hand, the price of chi-square obtained is not significant $\left(\chi^{2}=\right.$ $168,849 ; p<0.05)$, indicating that there is no difference between the models tested and the ideal model described by the data. In other words, the developed model represents the data in the field.

\section{Indicator Parameter Identification}

In the analysis process through CFA, after obtaining information that the model tested has a precision with the model, the next step is to identify the indicator parameters forming measurement construct. In this case, the indicator in question is the competence group. Table 1 explains the intercept and factor weighting in all competence groups in both the professional dimension and the pedagogic dimension. The intercept price indicates the average value of the teacher's score in the competence group, while the factor weight indicates the relationship between the competence group and the competence.

Table 1. Comparison of weight Factors among Competence Groups

\begin{tabular}{|c|c|c|c|c|c|c|c|}
\hline \multicolumn{4}{|c|}{ Professional Dimensions } & \multicolumn{4}{|c|}{ Pedagogic Dimensions } \\
\hline $\begin{array}{l}\text { Competence } \\
\text { Group }\end{array}$ & Intercept & $\begin{array}{l}\text { Weight } \\
\text { Factor }\end{array}$ & $\%$ & $\begin{array}{l}\text { Competence } \\
\text { Group }\end{array}$ & Intercept & $\begin{array}{l}\text { Weight } \\
\text { Factor }\end{array}$ & $\%$ \\
\hline Nirmana Dwimatra & 4.13 & 0.827 & 68 & Characteristics of Learners & 2.99 & 0.727 & 53 \\
\hline Trimatra Nirmana & 3.98 & 0.768 & 59 & $\begin{array}{l}\text { Creativity Development of } \\
\text { Learners }\end{array}$ & 3.50 & 0.767 & 59 \\
\hline $\begin{array}{l}\text { Introduction to Graphic } \\
\text { Communication Media }\end{array}$ & 4.71 & 0.804 & 65 & $\begin{array}{l}\text { Theory and Principles of Ed- } \\
\text { ucational Learning }\end{array}$ & 3.82 & 0.851 & 72 \\
\hline $\begin{array}{l}\text { Production of Graphic } \\
\text { Communication Media }\end{array}$ & 4.18 & 0.795 & 63 & Curriculum Development & 3.36 & 0.856 & 73 \\
\hline $\begin{array}{l}\text { Learning and Designing } \\
\text { Short Film }\end{array}$ & 4.34 & 0.817 & 67 & $\begin{array}{l}\text { Learning Device Develop- } \\
\text { ment }\end{array}$ & 3.86 & 0.868 & 75 \\
\hline Moving Image Technique & 3.66 & 0.723 & 52 & ICT Application in Learning & 3.80 & 0.693 & 48 \\
\hline $\begin{array}{l}\text { Video and Audio Pro- } \\
\text { cessing }\end{array}$ & 4.76 & 0.842 & 71 & Learning Communication & 3.01 & 0.721 & 52 \\
\hline 2D Animation & 4.02 & 0.822 & 68 & $\begin{array}{l}\text { Assessment and Evaluation } \\
\text { of Learning }\end{array}$ & 3.10 & 0.786 & 62 \\
\hline 3D Animation & 4.83 & 0.819 & 67 & Learning Completion & 2.15 & 0.600 & 36 \\
\hline Interactive Multimedia & 3.93 & 0.818 & 67 & Reflective Journal of PTK & 2.82 & 0.541 & 53 \\
\hline
\end{tabular}


In the professional dimension, the results of the analysis show that the level of teacher's ability in the 3D Animation Competence Group (Professional-9) is the highest. On the other hand, the highest factor weights were found in the Competence Group of Video and Audio Processing (Professional-7). In the pedagogic dimension, the highest intercept prices are consecutively found in the Competence Groups Learning Tool Development (Pedagogic-5), Educational Learning Theory and Principles (Pedagogic-3) and Application of ICT in Learning (Pedagogic-6), while the highest factor weight is found in Pedagogic-5.

\section{DISCUSSION}

The results of the analysis through CFA find that the construct of teacher's competence described in the model has empirical support. This model represents the global concept of teacher's competence model in which the two dimensions involved are professionalism and pedagogy, each of which is manifested into ten competence groups. The accuracy of this model with the data shows that the structure of competence construct being assessed can be applied (applicable) for a variety of purposes. For example, for activities aimed at developing an assessment instrument of teacher's competence and developing interventions for teacher's competence improvement; this model can be used as a guide for its development.

In general, the structure and order of constructs in the model show that: (a) the division of teacher's competence is divided into two dimensions, namely professional and pedagogic supported by data. This consequence shows that both are independent constructs that need to be seen as two distinct attributes attached to one person. Because they are different attributes, reporting the teacher's ability in the form of scores between professional and pedagogic dimensions needs to be separated. (b) The division of the constructs into ten competence groups is also supported by the data. One of the implications is that the intervention to increase the teacher's competence can be done by considering each competence group. If the competence group is hierarchical content (gradation from low to high level), the intervention implemented in the form of training can be done gradually. If the competence group is seen as non-hierarchical constructs, the ten competence groups are all owned by teachers in varying degrees. This is because the ten competence groups make a balanced contribution (see Table 1). The implication is if there is a teacher who has advantages in competence group one while the other teachers in competence group five. Using this approach, the intervention is based on which competence group is the weakest the teachers possess.

The competence model tested in this study implies that competence is not only to differentiate teachers into different levels based on their competence which ultimately is the compensation given to those who are competent. On the contrary, this model illustrates that competence should be seen as a non-hierarchical concept which is indispensable for the improvement of human resources. Which groups of dimensions are weak, that is where the intervention is focused. Defining non-hierarchical competence groups will provide some benefits because the assessment will produce a profile taken as a report card for teachers. By knowing the teacher's competence profile, the policy makers will be able to provide appropriate training interventions and match the needs of teachers.

Teacher professions have increasingly required more varied teacher's skills as the required knowledge, attitude, and skills. Future teachers are multitalented professionals collaborating with cross-functional and multi-disciplinary peers and groups and at the same time the teacher should master the materials taught to students. In addition to the mastery of the subject matter and pedagogical skills, knowledge of ICT also needs to be mastered (Martin \& Pennanen, 2015).

The aspect that needs to be considered is the importance of policy makers in vocational education in order to maintain and improve the leadership and organizational culture of schools to satisfy stakeholders (Elmunsyah, 2014; Pratiwi, et al., 2017).

\section{CONCLUSION}

Based on the results, it can be conclude that the construct of teacher's competence model has two dimensions, which are professionalism and pedagogy. The competence model whish tested in this study implies that a competence is not only to differentiate teachers into different levels based on their competence which ultimately is the compensation given to those who are competent. In addition, it shows that the model is able to explain the teacher's phenomenon in the real world. Therefore, the evaluation process against the teacher's competence and the intervention in the competence development using this model are empirically support. 
Furthermore, by knowing the teacher's competence profile, the policy makers will be able to provide appropriate training interventions and match the needs of teachers. This is need because the requirements of the current teacher proffesion has increase. The future teacher should have the various

\section{REFERENCES}

Baumert, J. \& Kunter, M. 2013. The COACTIV Model of Teachers' Professional Competence. In M. Kunter, J. Baumert, W. Blum, U. Klusmann, S. Krauss, \& M. Neubrand (Eds.), Cognitive activation in the mathematics classroom and professional competence of teachers: 25-48. Boston, MA: Springer.

Bertschy, F., Künzli, C., \& Lehmann, M. 2013. Teachers' competencies for the implementation of educational offers in the field of education for sustainable development. Sustainability, 5 (12): 5067-5080.

Cabaní, M.L.P., Bosch, J.J., \& Argelagós, E. 2014. Testing a model of Competence-based Teaching. Procedia-Social and Behavioral Sciences, 143: 31-34.

Chalmers University of Technology. 2013. University appointment regulations for teaching and research faculty at Chalmers. Appointment regulations, revision 2013-06-28.

Drovnikov, A.S., Nikolaev, E.L., Afanasev, A.S., Ivanov, V. N., Petrova, T. N., Tenyukova, G.G., \& Povshednaya, F.V. 2016. Teachers professional competence assessment technology in qualification improvement process. International Review of Management and Marketing, 6 (1): 111-115.

Elmunsyah, H. 2014. A National Education Policy-based ICT Model for Indonesian Vocational High Schools (VHS). Global Journal of Engeneering Education, 16 (3): 136-140. (http:// www.wiete. com.au/journals/GJEE/Publish/vol16 no3/06Elmunsyah-H.pdf)

Elmunsyah, H., Hidayat, W.N., \& Asfani, K. 2019. Interactive learning media innovation: utilization of augmented reality and pop-up book to improve user's learning autonomy. Journal of Physics: Conference Series, 1193 (1): 012031.

Gokce, E. 2015. The development of a scale to determine general competency for primary school teachers in Turkey: A validity and reliability study. The Anthropologist, 20 (1-2): 360-368.

Gourier, L. 2010. Modeling pedagogical competences of technical university teacher. In Joint International IGIP-SEFI Annual Conference.

Grealish, L. 2006. Learning to be a professional: two models of competence and related learning abilities, not only knowledge, attitude, and skill. They also have the ability to collaborating with cross functional and multidisciplinary. In addition they also should be able adopted the ICT into the learning environment.

strategies. Journal of Religion, Spirituality \& Aging, 18 (4): 207-225.

Hu, L. \& Bentler, P.M. (1999). Cutoff criteria for fit indexes in covariance structure analysis: Conventional criteria versus new alternatives. Structural Equation Modeling: A Multidisciplinary Journal, 6 (1): 1-55.

Jovanova-Mitkovska, S. \& Hristovska, D. 2011. Contemporary teacher and core competences for lifelong learning. Procedia-Social and Behavioral Sciences, 28: 573-578.

Kamalova, L.A. 2015. Formation of Professional Competences of" Primary Education" Profile Students While the Studying Process at the University. Review of European Studies, 7 (1): 94-100.

Liakopoulou, M. 2011. Teachers' pedagogical competence as a prerequisite for entering the profession. European Journal of Education, 46 (4): 474-488.

Martin, A. \& Pennanen, M. 2015. Mobility and transition of pedagogical expertise in Finland. Jyväskylä: University of Jyväskylä.

Molenaar, W.M., Zanting, A., van Beukelen, P., de Grave, W., Baane, J.A., Bustraan, J.A., Engbers, R., Fick, T.E., Jacobs, J.C., \& Vervoorn, J.M. (2009). A framework of teaching competencies across the medical education continuum. Medical Teacher, 31 (5), 390-396.

Piri, E., Keshtiaray, N., \& Saadatmand, Z. 2016. Designing a Model of Personality Traits Desirable for Teacher Training Courses for Student Teachers. Turk Psikoloji Dergisi, 31 (77): 125133.

Prachagool, V., Nuangchalerm, P., Subramaniam, G., \& Dostal, J. (2016). Pedagogical decision making through the lens of teacher preparation program. Journal for the Education of the Gifted Young Scientists, 4 (1): 41-52.

Pratiwi, A.S., Sudjimat, D.A. \& Elmunsyah, H. 2017. Kontribusi Daya Kreativitas Dan Kinerja Prakerin Terhadap Hasil Uji Kompetensi Keahlian. Jurnal Pendidikan, 2 (2): 285-293.

Rizza, M. \& Elmunsyah, H. 2018. The Effect of Laboratory Facilities and Teacher Competence on Student Learning Outcomes in Vocational High School (VHS). Letters in Information Technology Education, 1 (1): 18-21. 
Santos, K.O.B., Carvalho, F.M., \& de Araújo, T. M. 2016. Factor structure and validity indicators of the job content questionnaire: Discussing stress in the work contexts. Psychology, 7: 1424-1437.

Tasiam, F.J., Kustono, D., Purnomo, \& Elmunsyah, H. 2017. Fostering pedagogic competence of electrical engineering vocational high school teacher in facing ASEAN economic community. European Journal of Education Studies, 3 (8): 558-571.
Usoltzev, A., Shamalo, T., \& Scherbakova, V. 2016. Problems of Control by the Technique Creation of Quality Estimation of Electronic of Training in Realization Conditions of Competition Approach. In M. Mkrttchian (Ed.), Handbook of Research on Estimation and Control Techniques in ELearning Systems, Chapter 38, pp. 543-558). Moscow: IGI Global. 